\title{
On the performance of fish stock parameters derived from VIT pseudo-cohort analysis
}

\author{
HANS-JOACHIM RÄTZ ${ }^{1,2}$, ANNA CHEILARI ${ }^{1}$ and JORDI LLEONART ${ }^{3}$ \\ ${ }^{1}$ Joint Research Centre, Institute for Protection and Security of the Citizen, Maritime Affairs Unit G.04, TP 051, \\ 21020 Ispra, (VA), Italy. E-mail: hans-joachim.raetz@jrc.ec.europa.eu \\ ${ }^{2}$ Johann Heinrich von Thünen-Institut, Federal Research Institute for Rural Areas, Forestry and Fisheries, \\ Institute for Sea Fisheries, Palmaille 9, 22767 Hamburg, Germany. \\ ${ }^{3}$ Institut de Ciències del Mar, CSIC, Passeig Marítim de la Barceloneta, 37-49, 08003 Barcelona, Spain.
}

SUMMARY: The comparison of VIT model results with those of the virtual population analysis assessment of the cod stock in the Skagerrak, North Sea and Eastern Channel established by the International Council for the Exploration of the Sea (ICES) reveal that overall trends in fishing mortality and stock size are well captured over a period of three decades (19631992). However, the implications of the equilibrium assumption (steady state) made by the VIT model are enormous, as it forces strong inter-annual variations in the estimated fishing mortality, especially in years when the age composition shows strong year class effects. Estimated VIT output parameters should be carefully interpreted when the assessed stock suffers from reduction in abundance and high exploitation, as this condition is likely to deviate from steady state. The VIT estimates of the virgin stock biomass appear very variable, extremely high and fairly dependent on annual stock size estimates. Their use in fisheries management as a realistic biological stock biomass reference is not recommended. The VIT estimates of $\mathrm{F}_{0.1}$ and $\mathrm{F}_{\max }$ are found to be in line with the ICES estimates. Therefore, model results should allow qualitative conclusions regarding the status of marine living resources in relation to a target reference of exploitation rate. Quantitative conclusions regarding the assessment of the exploitation status are only recommended when the model is applied to short time series of consecutive annual data and the resulting variation in the estimated stock parameters appears reasonably low. As such, the model results may form the basis for scientifically sound fisheries management advice covering the actual state of the stock as well as medium-term forecasts of catch and biomass under different options.

Keywords: VPA pseudo-cohort analysis, VIT program, accuracy, user recommendations.

RESUMEN: CALIDAD DE LOS PARÁMETROS POBLACIONALES DERIVADOS DEL ANÁLISIS DE PSEUdO-COHORTES DE VIT. - LaS comparaciones de los resultados del modelo VIT con los del método de VPA, empleado para la evaluación del stock de bacalao en el Skagerrak, Mar del Norte y la parte oriental del Canal de la Mancha, muestran que las tendencias generales de la mortalidad por pesca y del tamaño del stock aparecen bien representadas en un período de tres décadas (1963-1992). No obstante las implicaciones de la asunción de equilibrio (estado estacionario) del modelo VIT son muy grandes y fuerzan importantes variaciones interanuales de la mortalidad por pesca, especialmente en aquellos años en que la composición de edades muestra el efecto de clases anuales fuertes. Los parámetros estimados por VIT deben ser cuidadosamente interpretados cuando el stock evaluado presenta una fuerte reducción de su abundancia y una elevada explotación ya que esta condición lo aleja del estado estacionario. Las estimaciones de la biomasa virgen son muy variables, extremadamente altas y dependientes de las estimaciones del stock. No se recomienda su uso como punto de referencia de una biomasa realista en un contexto de gestión pesquera. Las estimaciones de $\mathrm{F}_{0.1}$ y $\mathrm{F}_{\max }$ son similares a las estimaciones de ICES. Los resultados del modelo permiten la obtención de conclusiones más bien cualitativas sobre el estado de los recursos marinos en referencia a la tasa de explotación. Las conclusiones cuantitativas sobre la evaluación del estado de explotación son recomendables solamente en el caso de que se aplique el modelo a una serie corta de datos anuales consecutivos y cuando la variación de los parámetros estimados sea razonablemente baja. Los resultados del modelo pueden fundamentar las bases de un correcto asesoramiento del estado real del stock así como predicciones de biomasa, bajo diversas alternativas de gestión, a corto y medio plazo.

Palabras clave: VPA análisis de pseudocohortes, programa VIT, precisión, recomendaciones de uso. 


\section{INTRODUCTION}

Age-based fish stock assessments are 'datahungry' and the precision of the model outcomes are dependent on both the quality and the quantity of the input data. Classical virtual population analysis (VPA) input data sets usually comprise matrices of international catch at age in number and general biological information regarding growth (weight at age in the stock and the catches), natural mortality and maturity ogives at age as minimum requirements (VPA; Baranov, 1918; Fry, 1949; Gulland, 1965; Beverton and Holt, 1957; Ricker, 1975; Megrey, 1989). Catches and biological parameters should be representative of all fish removed from the stock (i.e. including discards) over the longest time series available. Only sufficiently precise and long time series of these stock parameters over at least one generation would allow representative conclusions about the state of the stock and its state of exploitation to be drawn for the purpose of achieving sustainable high yields.

Despite the ever-growing demand for suitable advice to fisheries management, the current data situation for many fisheries is far from meeting such minimum requirements for standard VPA. The main reasons for this poor information are inadequate sampling of commercial landings and discards and the difficulty of ageing the species caught.

The VIT program (Lleonart and Salat, 1992) was especially developed to assess exploited fish stocks in data-poor situations when information about annual catch at length or age is limited to a short period of individual or few consecutive years. The software was initially developed for MS-DOS but the Windows version (Lleonart and Salat, 1997) can be downloaded from http://www.mefisto.info/ Vit4wind.zip. It is frequently used, especially to assess the Mediterranean fish stocks (Demestre and Lleonart, 1993; Sardà and Lleonart, 1993; Aldebert et al., 1993; Oliver, 1993; Pertierra and Perrota, 1993; Sardà et al., 1998; Anon., 2006; Bahamon et al., 2007; Dhieb et al., 2007). The VIT program has become a common assessment tool applied in the framework of the General Fisheries Commission for the Mediterranean (GFCM), as has been documented in the various reports of the Subcommittee on Stock Assessment since its inception in 1999 (http:// www.gfcm.org/gfcm/topic/16092/en). Furthermore, stock assessments conducted by the Mediterranean Subgroup of the Scientific, Technical and Economic Committee for Fisheries (STECF) of the European
Commission were also based on the VIT program (Cardinale et al., 2008).

To test the performance of this commonly used assessment approach, this paper presents the application of the VIT program to one of the best monitored and analysed European fish stocks, the cod stock in the Skagerrak, North Sea and Eastern Channel (ICES, 2008). Conclusions drawn from comparative assessments provide insight into the accuracy and precision of the VIT results and their applicability for scientific fisheries management advice.

\section{MATERIALS AND METHODS}

As the input to the VIT program, the ICES assessment data of North Sea cod (including the Skagerrak and the Eastern Channel) in 2007 were adopted (ICES, 2008). The relevant input data and results of that fish stock assessment represent:

- Annual catch at age including discards.

- Weight at age in the catch, including discards and weight at age in the stock at the beginning of the year.

- Natural mortality and maturity at age.

- Trends of resulting stock parameters such as recruits, total (TSB) and spawning stock biomass (SSB), catch, yield/SSB ratio, and average fishing mortality mean F over ages 2-4.

We restricted the use of the assessment-relevant data and comparative analyses to the first 3 decades of the data from 1963 to 1992, as the ICES working group considered the international catch figures from 1993 onwards to be incomplete. The quality of the commercial landings and catch-at-age data for this stock deteriorated in the 1990s following reductions in the TAC without associated control of fishing effort (ICES, 2008). Such a bias is expected to result in a retrospective underestimation of fishing mortality and an overestimation of spawning stock. The limitation of our analyses to the early and converged part of the VPA implies robustness to methodological aspects and to updates with more recent data. The assessment method recently used by the ICES working group was the B-ADAPT model, which specifically accounts for any kind of missing fish not allocated to catches or natural death (ICES, 2008).

The annual catches and age compositions of the period 1963-1992 were separately used as an input to the VIT program module. Biological input data on weight, natural mortality $(\mathrm{M})$ and maturity at age 
TABLE 1. - Von Bertalanffy growth parameters and length-weight relation parameters for unsexed North Sea cod (adopted from FishBase: http://www.fishbase.org/).

\begin{tabular}{lcccc}
\hline $\mathrm{L}_{\text {inf }}$ & $\mathrm{k}$ & $\mathrm{t}_{0}$ & $\mathrm{a}$ & $\mathrm{b}$ \\
\hline $132 \mathrm{~cm}$ & 0.2 year $^{-1}$ & -0.2 years & 0.0104 & 3.0 \\
\hline
\end{tabular}

were also adopted from the ICES working group report (ICES, 2008). Von Bertalanffy (1938) growth parameters and the length-weight relation parameters were adopted from FishBase: http://www.fishbase. org/ (Table 1). The value 0.9 year $^{-1}$ was applied as an input to terminal fishing mortality in order to start the standard VPA calculations for each individual year by interpreting the age groups of a given year as age groups of a single cohort (pseudo-cohort). All other program requirements were kept at the default option. The program is constructed to conduct a virtual population analysis (VPA), and assuming a steady state, to estimate the population size. Catch and fishing mortality were related to population number by the classic catch equation of Gulland (1965).

The VIT-estimated fishing mortalities at age and average fishing mortality over the ages $2-4$ years, stock numbers at age and their sums and spawning stock sizes were compared with the VPA estimates from the ICES working group (ICES, 2008), which are assumed to be the "true" values. Quantitative deviations are analysed and interpreted in detail.

Total and spawning stock biomass values were derived from the VIT population estimates as numbers at age (at the beginning of each year) multiplied with weights and maturity at age, respectively. The estimates of total stock biomass were compared with the VIT estimates of the virgin biomass, a parameter which has been used as a biological reference point.

As $\mathrm{F}_{0.1}$ and $\mathrm{F}_{\max }$ are considered reference candidates for sustainable exploitation targets, we also computed the classical yield per recruit (Thompson and Bell, 1934; Beverton and Holt, 1957; Rivard, 1982; Sinclair, 1999) applying the VIT model. The results are compared with $\mathrm{F}_{0.1}$ and $\mathrm{F}_{\max }$ values estimated by ICES (ICES, 2008).

We give no further details as the applied assessment modules and underlying mathematical functions are well described in the literature (Lleonart and Salat, 1992; Hart and Reynolds, 2002).

TABLE 2. - Estimates of fishing mortality (F) at ages 1-7 and averaged over ages 2-4 years (F2-4), spawning stock biomass (SSB), total stock biomass (TSB), virgin stock biomass (VSB), and the slope parameters of yield per recruit functions $\mathrm{F}_{0.1}$ and $\mathrm{F}_{\text {max }}$ as derived from the VIT program, 1963-1992.

\begin{tabular}{|c|c|c|c|c|c|c|c|c|c|c|c|c|c|}
\hline Year & $\mathrm{F} 1$ & $\mathrm{~F} 2$ & F3 & $\mathrm{F} 4$ & F5 & F6 & F7 & $F(2-4)$ & $\mathrm{SSB}(\mathrm{t})$ & TSB (t) & VSB (t) & $\mathrm{F}_{0.1}$ & $\mathrm{~F}_{\max }$ \\
\hline 1963 & 0.118 & 1.249 & 0.493 & 0.512 & 1.017 & 2.510 & 2.546 & 0.751 & 58112 & 205158 & 2935807 & 0.098 & 0.173 \\
\hline 1964 & 0.093 & 0.485 & 0.897 & 0.497 & 0.432 & 0.967 & 1.063 & 0.626 & 94557 & 259912 & 2605876 & 0.113 & 0.207 \\
\hline 1965 & 0.450 & 0.762 & 0.639 & 0.868 & 0.582 & 0.485 & 0.746 & 0.756 & 114482 & 363178 & 5362036 & 0.129 & 0.212 \\
\hline 1966 & 0.381 & 0.825 & 0.925 & 0.541 & 0.649 & 0.550 & 0.408 & 0.764 & 131629 & 434672 & 6617466 & 0.145 & 0.244 \\
\hline 1967 & 0.176 & 0.780 & 0.802 & 0.757 & 0.516 & 0.686 & 0.779 & 0.780 & 145930 & 480106 & 6246347 & 0.140 & 0.242 \\
\hline 1968 & 0.095 & 0.722 & 0.856 & 0.682 & 0.877 & 0.513 & 0.697 & 0.753 & 149646 & 521009 & 6556971 & 0.143 & 0.249 \\
\hline 1969 & 0.025 & 0.320 & 0.668 & 0.727 & 0.573 & 0.905 & 0.459 & 0.572 & 153419 & 419536 & 3668861 & 0.132 & 0.252 \\
\hline 1970 & 0.415 & 0.470 & 0.441 & 0.686 & 0.837 & 0.597 & 0.781 & 0.532 & 170330 & 493961 & 5539600 & 0.107 & 0.181 \\
\hline 1971 & 0.504 & 1.379 & 0.463 & 0.342 & 0.735 & 0.702 & 0.532 & 0.728 & 182662 & 632885 & 11841538 & 0.131 & 0.211 \\
\hline 1972 & 0.067 & 1.241 & 1.074 & 0.341 & 0.272 & 0.592 & 0.726 & 0.885 & 166753 & 580001 & 9262402 & 0.151 & 0.257 \\
\hline 1973 & 0.322 & 0.364 & 1.076 & 0.971 & 0.381 & 0.336 & 0.623 & 0.804 & 130964 & 431728 & 6084470 & 0.169 & 0.297 \\
\hline 1974 & 0.447 & 0.797 & 0.297 & 0.900 & 0.739 & 0.328 & 0.243 & 0.665 & 162413 & 457545 & 6369324 & 0.140 & 0.233 \\
\hline 1975 & 0.562 & 0.728 & 0.575 & 0.276 & 0.976 & 0.806 & 0.402 & 0.526 & 150466 & 417101 & 6346152 & 0.100 & 0.163 \\
\hline 1976 & 0.437 & 1.482 & 0.659 & 0.548 & 0.263 & 1.024 & 1.065 & 0.896 & 110046 & 377985 & 8825401 & 0.152 & 0.242 \\
\hline 1977 & 1.049 & 1.000 & 0.958 & 0.447 & 0.419 & 0.264 & 0.698 & 0.802 & 115795 & 452013 & 11929974 & 0.136 & 0.208 \\
\hline 1978 & 0.104 & 1.737 & 0.589 & 0.798 & 0.646 & 0.528 & 0.378 & 1.041 & 100408 & 511676 & 8533160 & 0.177 & 0.302 \\
\hline 1979 & 1.050 & 0.802 & 1.436 & 0.463 & 0.918 & 0.491 & 0.565 & 0.900 & 99668 & 552408 & 14608328 & 0.135 & 0.207 \\
\hline 1980 & 1.437 & 0.933 & 0.920 & 1.096 & 0.497 & 0.709 & 0.675 & 0.983 & 102880 & 639042 & 22569919 & 0.138 & 0.216 \\
\hline 1981 & 0.285 & 1.355 & 0.966 & 0.756 & 0.989 & 0.505 & 0.948 & 1.026 & 108757 & 547624 & 10608766 & 0.164 & 0.277 \\
\hline 1982 & 0.545 & 0.504 & 1.271 & 0.724 & 0.640 & 1.039 & 0.626 & 0.833 & 130385 & 559379 & 9442414 & 0.133 & 0.225 \\
\hline 1983 & 0.202 & 1.174 & 0.644 & 0.967 & 0.647 & 0.680 & 0.824 & 0.928 & 102873 & 457236 & 6979094 & 0.158 & 0.269 \\
\hline 1984 & 1.176 & 0.817 & 1.132 & 0.454 & 0.826 & 0.628 & 0.612 & 0.801 & 92392 & 489099 & 13302560 & 0.120 & 0.184 \\
\hline 1985 & 0.184 & 1.427 & 0.780 & 0.934 & 0.408 & 0.823 & 0.619 & 1.047 & 76325 & 350752 & 6397200 & 0.178 & 0.304 \\
\hline 1986 & 1.443 & 0.452 & 1.170 & 0.648 & 0.847 & 0.402 & 0.804 & 0.757 & 77451 & 405103 & 12434485 & 0.114 & 0.174 \\
\hline 1987 & 0.118 & 1.806 & 0.460 & 1.039 & 0.504 & 0.816 & 0.414 & 1.102 & 65394 & 375616 & 6436259 & 0.176 & 0.298 \\
\hline 1988 & 0.132 & 0.689 & 1.646 & 0.480 & 0.941 & 0.675 & 0.754 & 0.938 & 58948 & 313479 & 4445926 & 0.169 & 0.291 \\
\hline 1989 & 0.763 & 0.657 & 0.741 & 1.281 & 0.396 & 0.938 & 0.621 & 0.893 & 62940 & 300135 & 5889002 & 0.143 & 0.232 \\
\hline 1990 & 0.177 & 1.443 & 0.738 & 0.688 & 1.148 & 0.407 & 0.935 & 0.956 & 44071 & 220064 & 3942062 & 0.153 & 0.268 \\
\hline 1991 & 0.402 & 0.636 & 1.041 & 0.591 & 0.534 & 1.042 & 0.657 & 0.756 & 52503 & 204477 & 3009315 & 0.136 & 0.219 \\
\hline 1992 & 0.720 & 0.973 & 0.627 & 0.990 & 0.580 & 0.587 & 1.048 & 0.863 & 53598 & 251146 & 4535885 & 0.138 & 0.225 \\
\hline
\end{tabular}




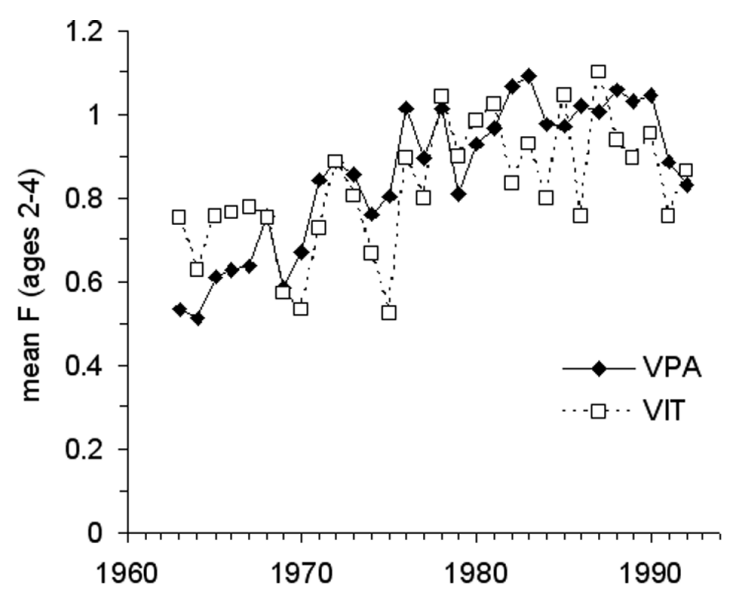

FIG. 1. - Cod in the Skagerrak, North Sea and Eastern Channel. Trends in average fishing mortality (F, ages 2-4) as estimated by VPA (ICES 2008) and VIT, 1963-1992. F values derived from VIT program are listed in Table 2
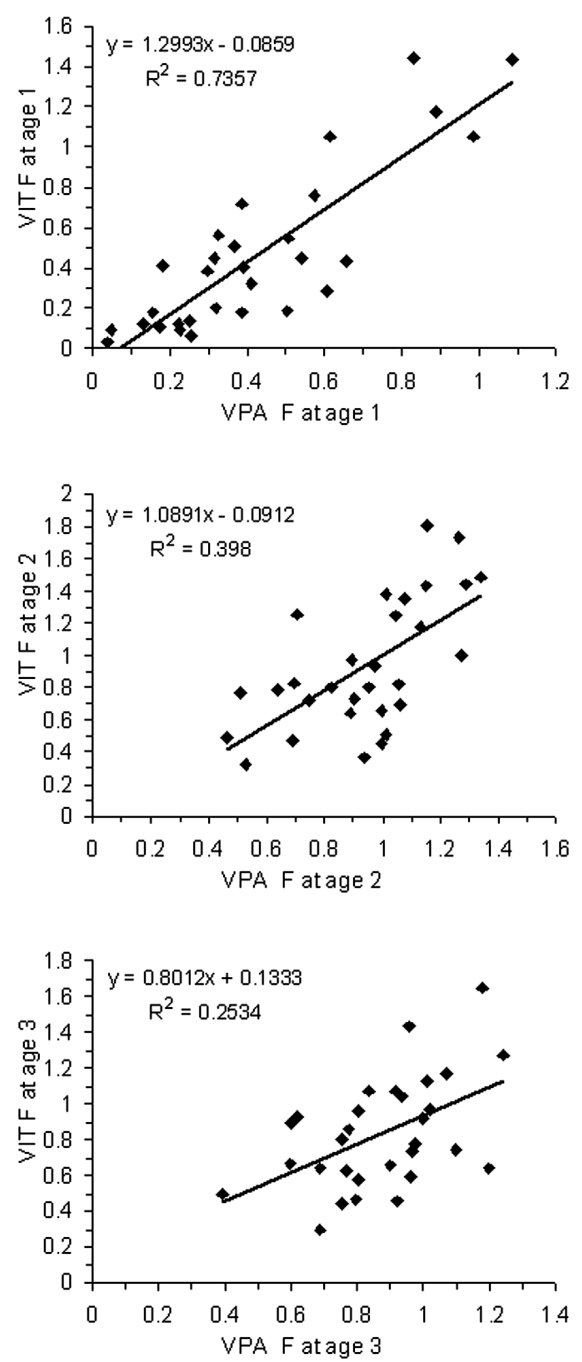

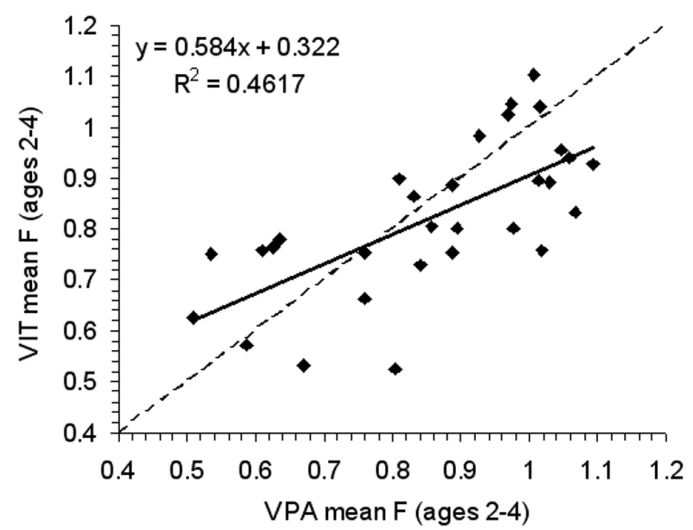

FIG. 2. - Cod in the Skagerrak, North Sea and Eastern Channel. Linear regression between average fishing mortality ( $F$, ages 2-4) as estimated by VPA (ICES 2008) (independent variable) and VIT (dependent variable), 1963-1992. Linear regression parameters and squared Pearson's correlation coefficient are shown in the figure. $\mathrm{F}$ values derived from the VIT program are listed in Table 2. The dashed line represents the slope of 1 .
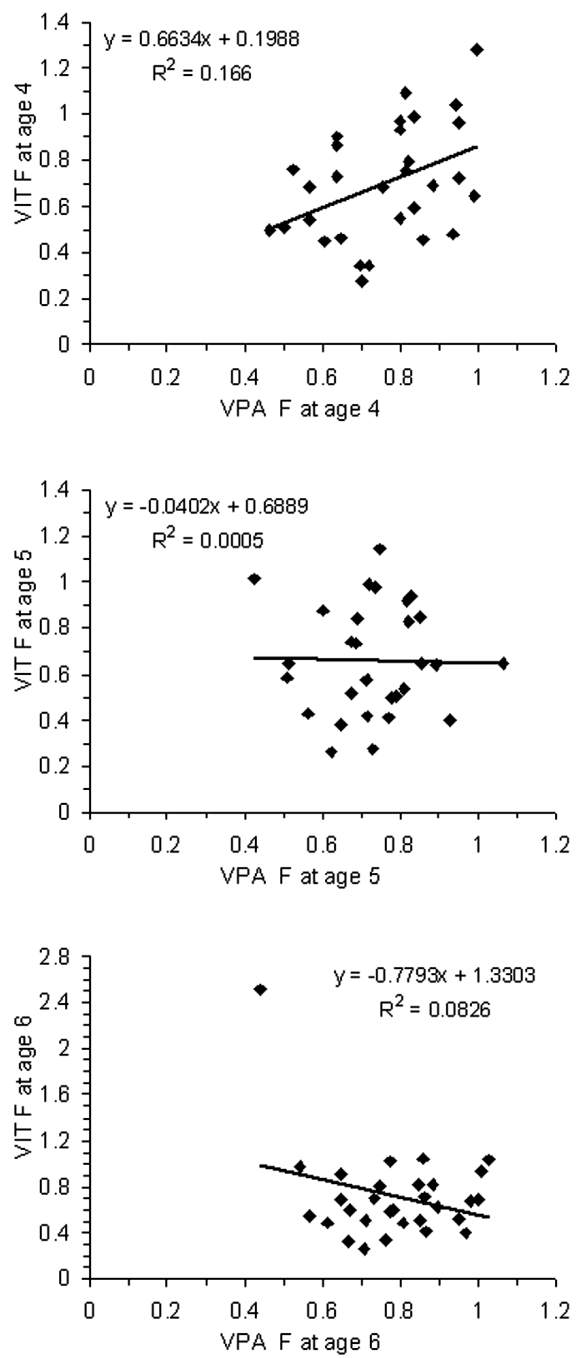

FIG. 3. - Cod in the Skagerrak, North Sea and Eastern Channel. Fishing mortality (F) at ages 1-6 as estimated by VPA (ICES 2008) (independent variable) and VIT (dependent variable), 1963-1992. Linear regression parameters and squared Pearson's correlation coefficients are shown in the figures. F values derived from VIT program are listed in Table 2. 

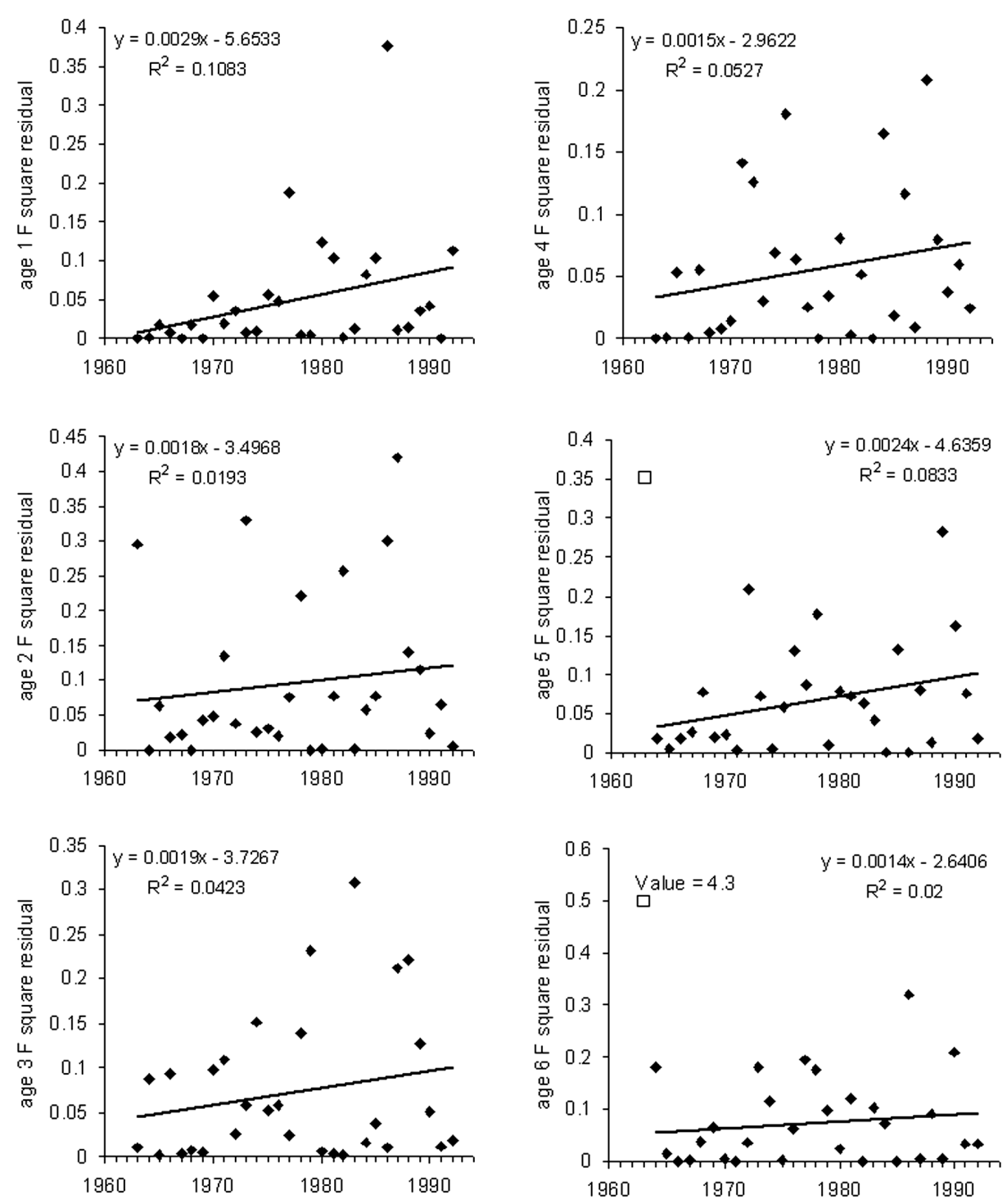

FIG. 4. - Cod in the Skagerrak, North Sea and Eastern Channel. Trends in square residuals between fishing mortality (F) at ages 1-6 as estimated by VPA (ICES 2008) and VIT, 1963-1992. Linear regression parameters and squared Pearson's correlation coefficients are shown in the figures. Note that the values of ages 5 and 6 in 1963 indicated as open squares are excluded from the estimation of the linear trends. F values derived from VIT program used to estimate the square residuals are listed in Table 2.

\section{RESULTS}

The VIT estimates of fishing mortality at age are listed in Table 2. The fishing mortalities averaged over the ages 2-4 [F(2-4)], as adopted from the VPA using B-ADAPT (ICES, 2008) and estimated by VIT, are illustrated in Figure 1 and display an overall increasing trend over three decades from 1963 to 1992. It can be seen that the general increase in $\mathrm{F}(2$ 4) over time is well captured by VIT. However, the scatter plot and the significant regression between the two series, namely the average Fs derived from the VPA and from the VIT, indicate low precision in the annual estimates. The deviation of the VIT esti- mates from the VPA estimates of average Fs often appears to be in the range of \pm 0.1 or higher (Fig. 2 ), which explains the rather low squared Pearson's correlation coefficient. As the slope of the regression is significantly different from 1 (lower) and the intercept significantly different from 0 (higher), average Fs (2-4) derived from VIT have the tendency to be overestimated when $\mathrm{F}$ is low and underestimated when $\mathrm{F}$ is high (Fig. 2). This effect may have different causes and was therefore analysed further.

Figure 3 displays linear regressions and correlations in $\mathrm{F}$ at ages 1 to 6 . Age group 7 is not displayed in Figure 3 as this oldest age group represents a plus group including also all older age groups. It can be 


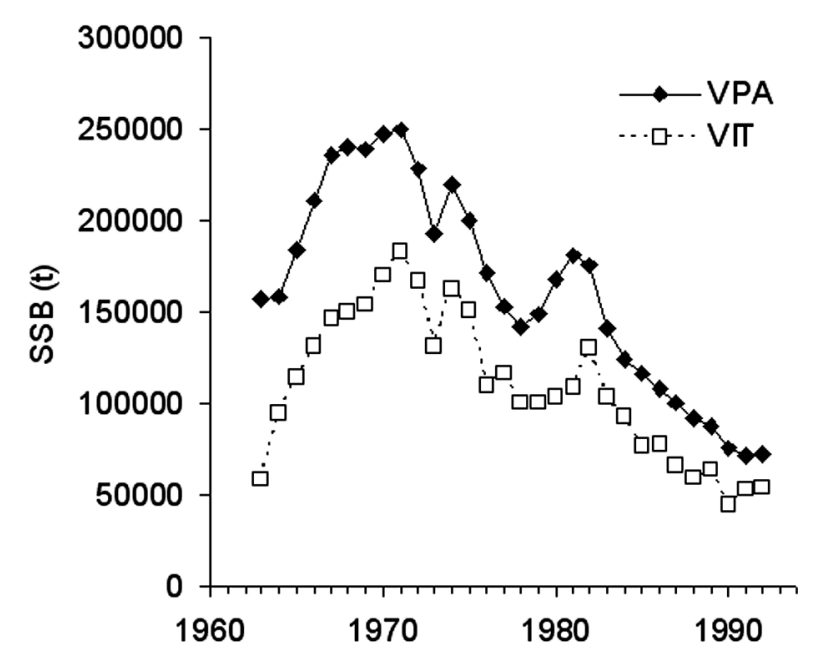

FIG. 5. - Cod in the Skagerrak, North Sea and Eastern Channel. Trends in spawning stock biomass at ages 1-7+ as estimated by VPA (ICES 2008) and VIT, 1963-1992. Values of SSB are listed in Table 2.

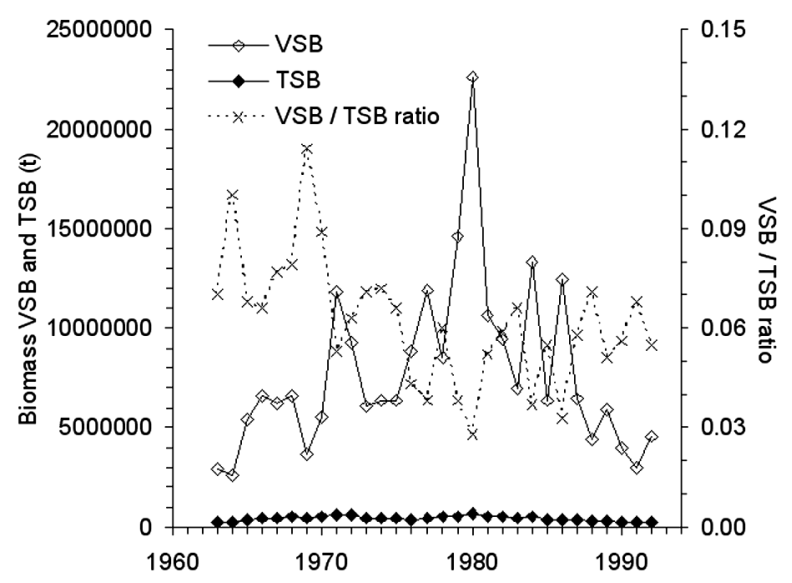

FIG. 6. - Cod in the Skagerrak, North Sea and Eastern Channel. Virgin (VSB) and total stock biomass (TSB) and the ratio between them as estimated by VIT, 1963-1992. Values of SSB are listed in Table 2.

concluded that, from age 1 up to age 3, the Fs derived from the VIT program are similar to the VPA estimates, but with a low and decreasing coincidence with increasing age. Differences in individual years can be substantial, and the F estimates of age groups 5 and 6 derived from VIT and VPA are not significantly correlated. Note that the outlier in age 6 , corresponding to the year 1963, is responsible for the negative sign of the correlation.

Figure 4 indicates increasing trends in square residuals between the Fs derived from VPA and VIT for age groups 1 to 6 over the period 1963-1992. For age groups 5 and 6 , the initial values were excluded from the estimation of linear trends as they are out of range and believed not to be representative. The differences between $\mathrm{F}$ estimates from VIT and from

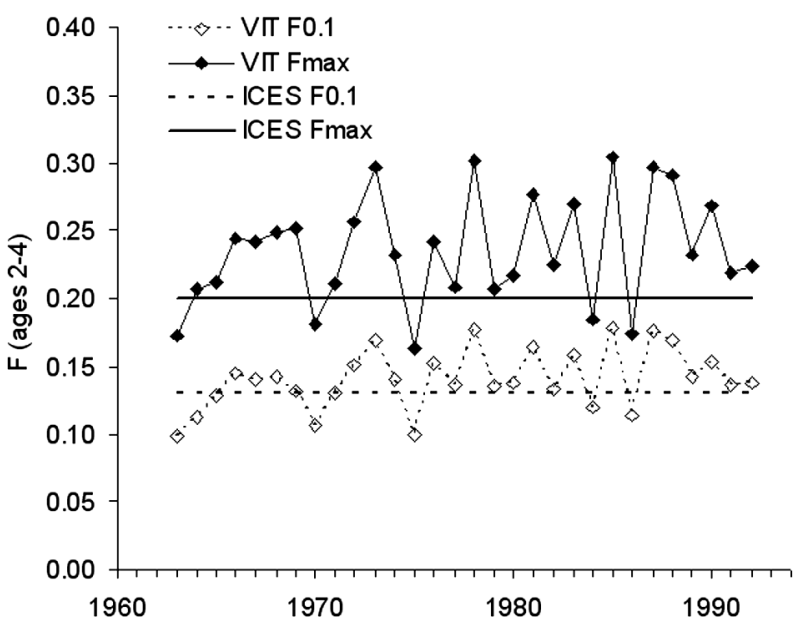

FIG. 7. - Cod in the Skagerrak, North Sea and Eastern Channel. $F_{0}$ and $\mathrm{F}_{\max }$ and their actual values as estimated by VIT, 1963-1992. The horizontal lines represent the $\mathrm{F}_{01}$ and $\mathrm{F}_{\text {pax }}$ as estimated by ICES (2008). Respective VIT values are listed in Table 2.

VPA become more significant over time when $\mathrm{F}$ increases and the stock size decreases.

As the stock in numbers at age estimates is derived from the estimates of fishing mortality, the age-structured stock size results are not presented. While relative trends in stock size are very similar, a consistent effect of underestimation by about one third also appears in absolute stock size, as can be seen in Figure 5, illustrating trends in SSB derived from both VPA (adopted from ICES, 2008) and VIT. The underestimation appears to be an effect of the steady state approximation algorithm used. Table 2 lists the VIT assessment results for spawning stock and total stock weights.

The VIT program provides estimates of the virgin biomass, which are listed in Table 2 . The trend in virgin biomass estimates is shown in Figure 6, together with total stock biomass estimates and the ratio between the two parameters. The correlation between the two amounts to 0.8 . The VIT estimates of the virgin stock biomass are extremely high in most years and vary between 2.5 and 22.5 million tons, with a long-term average of about 8 million tons. However, from 1963 to 1992 the ratio of estimated virgin and total stock biomass is fairly constant, varying frequently between $3 \%$ and $7 \%$.

Table 2 further lists VIT estimates of $\mathrm{F}_{0.1}$ and $\mathrm{F}_{\max }$. The trends of $\mathrm{F}_{0.1}$ and $\mathrm{F}_{\max }$ in 1963-1992 and the values estimated by ICES are shown in Figure 7. $\mathrm{F}_{0.1}$ and $\mathrm{F}_{\max }$ values are generally constant, with low annual variation over the entire period of 3 decades. The VIT estimates are insignificantly higher than the respective ICES estimates of $\mathrm{F}_{0.1}$ and $\mathrm{F}_{\max }$. 


\section{DISCUSSION}

The VIT program (Lleonart and Salat, 1992) was designed to analyse exploited marine populations based on catch data, structured by ages or sizes, from one or several gears, especially for data-poor situations in which long time series of age-structured data on catches are lacking. From the catch data with some auxiliary parameters and using Virtual Population Analysis (VPA) the program rebuilds the population numbers by age and mortality vectors. The main assumption is that of steady state because the program works with annual data only and interprets the length or age structure of the catches as 'pseudo-cohorts'.

Our comparative analyses of the VIT model results with those of a scientifically agreed VPA assessment of the cod stock in the Skagerrak, North Sea and Eastern Channel reveal that overall trends in fishing mortality and stock size are well captured over a period of three decades (1963-1992). Aldebert and Recasens (1996) also compared results derived from ordinary VPA with VIT outcomes and found high congruence based on a relatively short time series of European hake landings in the Gulf of Lions (1988-1991).

However, the implications of the equilibrium assumption (steady state) made by the VIT model are enormous, as it forces strong inter-annual variations in the estimated fishing mortality, especially in years when the age composition shows strong year-class effects (exceptionally weak or strong year classes at certain ages). In such cases, VIT stock size estimations are significantly underestimated. Both the inter-annual variation and the bias of the stock parameters observed largely prevent an application of VIT results to interpret the actual state of the stock or to make a short-term prognosis of catch and biomass. The precision of the annual stock parameters derived from VIT appears to be even lower when the cod stock was at low size and heavy overexploitation. This can be explained by the fact that strongly reduced stocks under heavy exploitation are likely to diverge from equilibrium conditions. Under such conditions even small variations in weak year-class strength may signify relatively important stock changes. According to the pseudo-cohort approach, if available data cover more than one year, we recommend applying the VIT model separately for each year and evaluating the stock status by considering the variability of parameters by year during the whole study period.
The VIT estimates of the virgin stock biomass are very variable, extremely high and fairly dependent on annual stock size estimates. Due to such properties, we recommend abstaining from interpreting or conveying the estimated virgin stock biomass or ratio between virgin and total estimated biomass values as a biomass reference point for fisheries management. This recommendation takes into account concerns regarding largely unknown density effects on fish growth and natural mortality due to interand intra-specific predation (cannibalism). Furthermore, the term of virgin stock biomass is likely to be misunderstood by stakeholders and fisheries managers and should be replaced by estimations of the non-exploited stock size, given appropriate data availability.

The VIT estimates of $\mathrm{F}_{0.1}$ and $\mathrm{F}_{\text {max }}$ are found to be in line with the ICES estimates. Their derivation from the yield per recruit analysis appears to result in quite stable estimates over time. The VIT model should be used to estimate $\mathrm{F}_{0.1}$ and $\mathrm{F}_{\max } . \mathrm{F}_{0.1}$ has recently been indicated as an acceptable approximation of management targets for sustainable fisheries consistent with high yields and low risk of collapse (United Nations, 2002; Anon., 2007; Kell and Fromentin, 2007).

The results of this comparative study suggest that the VIT model should be used for qualitative conclusions regarding the recent status of marine living resources in relation to a limit reference level of stock biomass or a target reference level of exploitation rate. Quantitative interpretations of the assessments of the relevant stock parameters are only recommended when the model is applied to short time series of more than a single year and the resulting variation of the parameters is reasonably low. As such, the model results may form the basis for scientifically sound fisheries management advice for medium-term periods. However, the likely low precision of the model results prevent their transfer to any precise short-term forecasts of catch possibilities and stock developments under different management options.

\section{REFERENCES}

Aldebert, Y. and L. Recasens. - 1996. Comparison of methods for stock assessment of European hake (Merluccius merluccius) in the Gulf of Lions (Northwestern Mediterranean). Aquat. Living Resour., 9: 13-22.

Aldebert, Y., L. Recasens and J. Lleonart. - 1993. Analysis of gear interactions in a hake fishery: The case of the Gulf of Lions 
(NW Mediterranean). Sci. Mar, 57(2-3): 207-217.

Anonymous. - 2006. Report of the eighth session of the subcommittee on stock assessment (SCSA), Rome, Italy, 11-14 September 2006. GFCM:SAC9/2006/Inf.8, 38 pp.

Anonymous. - 2007. Council Conclusion from the 2841st Agriculture and Fisheries Council meeting, Brussels, 17 December 2007. Implementing sustainability in EU fisheries through maximum sustainable yield. http://www.consilium.europa.eu/ ueDocs/cms_Data/docs/pressData/en/agricult/97717.pdf

Bahamon, N., F. Sardà and P. Suuronen. - 2007. Potential benefits from improved selectivity in the northwest Mediterranean multispecies trawl fishery. ICES J. Mar. Sci: J. Cons., 64(4): 757-760.

Baranov, F.I. - 1918. On the question of the biological basis of fisheries. Nauchnyi Issledovatelskii Ikhtiologicheskii Institut, Izvestiya 1: 81-128.

Bertalanffy, v., L. - 1938. A quantitative theory of organic growth. Hum. Biol., 10(2): 181-213.

Beverton, R.J.H. and S.J. Holt. - 1957. On the dynamics of exploited fish populations. Fishery Investigations, London HMSO, Ser 2(19).

Cardinale, Cardinale, M., H.-J. Rätz and A. Cheilari (eds.). - 2008. Scientific, Technical and Economic Committee for Fisheries (STECF) - Report of the SGMED-08-04 Working Group on the Mediterranean Part IV. EUR 23622 EN. Luxembourg (Luxembourg): OPOCE; 2008. JRC48910.

Demestre, M. and J. Lleonart. - 1993. Population dynamics of Aristeus antennatus (Decapoda: Dendrobranchiata) in the northwestern Mediterranean. Sci. Mar., 57(2-3): 183-189.

Dhieb, K., M. Ghorbel, O. Jarboui and A. Bouaïn. - 2007. Exploitation status and stock assessment by pseudo-cohort analysis of the bluefish, Pomatomus saltatrix, in the Gulf of Gabes (Tunisia). J. Mar. Biol. Ass. UK, 87: 1315-1319.

Fry, F.E.J. - 1949. Statistics of a lake trout fishery. Biometrics, 5: 27-67.

Gulland, J.A. - 1965. Estimation of mortality rates. Annex to Arctic Fisheries Working Group Report (meeting in Hamburg, January 1965), ICES CM 1965(3): 9 pp. (mimeo).

Hart, P.J.H. and J.D. Reynolds. - 2002. Handbook of Fish Biology and Fisheries. Blackwell Science Ltd, Oxford, UK.

ICES. - 2008. Report of the Working Group on the Assessment of Demersal Stocks in the North Sea and Skagerrak - Spring and Autumn (WGNSSK), 1-8 May and, ICES Copenhagen and By Correspondence. ICES CM 2007\ACFM:18 and 30: 1-960.

Kell, L.T. and J.-M. Fromentin. - 2007. Evaluation of the robust- ness of maximum sustainable yield based management strategies to variations in carrying capacity or migration pattern of Atlantic bluefin tuna (Thunnus thynnus). Can. J. Fish. Aquat., 64: 837-847

Lleonart, J. and J. Salat. - 1992. VIT, Programa de análisis de pesquerías. Inf. Téc. Sci. Mar. (CSIC, Barcelona), 168-169: 1-116.

Lleonart, J. and J. Salat. - 1997. VIT: software for fishery analysis. User's manual. FAO Comp. Infor. Ser. (Fish.). No. 11. Rome, FAO. 1-105.

Megrey, B.A. - 1989. Review and Comparison of Age-Structured Stock Assessment Models from Theoretical and Applied Points of View. American Fisheries Society Symposium 6: 8-48.

Oliver, P. - 1993. Analysis of the fluctuations observed in the trawl fleet landings of the Balearic Islands. Sci. Mar., 57(2-3): 219-227.

Pertierra, J.P. and R. Perrota. - 1993. On the population dynamics of sardine, Sardina pilchardus Walbaum, 1792, from the Catalan Sea (northwestern Mediterranean). Sci. Mar., 57(2-3): 235-241.

Ricker, W.E. - 1975. Computation and interpretation of biological statistics of fish populations. Bull. Fish. Res. Board Can., 191: $1-382$.

Rivard, D. - 1982. APL programs for stock assessment (revised). Can. Tech. Rep. Fish. Aquat. Sci., 1091: 1-146.

Sardà, F. and J. Lleonart. - 1993. Evaluation of norway lobster (Nephrops norvegicus L.) resource off the "Serola" bank off Barcelona (western Mediterranean). Sci. Mar., 57(2-3): 191-197.

Sardà, F., J. Lleonart and E.J. Cartes. - 1998. An analysis of the population dynamics of Nephrops norvegicus (L.) in the Mediterranean Sea. Sci. Mar., 62(Suppl. 1): 135-143.

Sinclair, A. - 1999. Biological Reference Points Relevant to a Precautionary Approach to Fisheries Management: An Example for the Southern Gulf of St. Lawrence Cod. Sci. Counc. Stud. NAFO, 32: 25-35.

Thompson, W.F. and F.H. Bell. - 1934. Biological statistics of the Pacific halibut fishery. Part 2: Effect of changes in intensity upon total yield and yield per unit of gear. Rep. Int. Fish. (Pacific Halibut) Comm., 8: 1-49.

United Nations. - 2002. Report of the World Summit on Sustainable Development. Johannesburg, South Africa, 26 August-4 September 2002. A/CONF.199/20*, United Nations publication, Sales No. E.03.II.A.1, ISBN 92-1-104521-5, 173 pp.

Scient. ed.: P. Martín.

Received February 10, 2009. Accepted June 4, 2009.

Published online December 9, 2009. 